\title{
Japan to study damage from Russian dumping
}

Tokyo. The uproar over Russia's dumping of low-level nuclear waste in the Japan Sea has drawn attention to a serious gap in attempts by Japan's marine scientists to monitor the possible contamination of a region in which thousands of tons of nuclear waste have been dumped by the former Soviet Union over the past 40 years.

It has also persuaded the two governments to bring forward the first meeting of a joint working group of specialists to discuss a survey of the dumping area which, ironically, had already been set up by the Russian president, Boris Yeltsin, during a visit to Tokyo earlier this month.

The disclosure by the environmental organization Greenpeace that Russia had resumed dumping in the Japan Sea occurred only days after Yeltsin signed a declaration in Tokyo expressing "serious concern" about such ocean dumping. Vehement protests from Japan and South Korea, backed by the United States, have already forced Russia to cancel plans to dump a further 800 tons of liquid waste.

But the 900 tons of low-level waste dumped by the Russian Navy under the gaze of Greenpeace cameras is relatively small

\section{Childhood leukaemias remain unexplained}

London. After a three-year investigation by the Health and Safety Executive (HSE), British health officials say they remain baffled by an outbreak of leukaemia among children of men living in the village of Seascale in Cumbria who worked at the nearby Sellafield nuclear plant.

The investigation confirmed findings first reported three years ago by the late Martin Gardner, then head of the Medical Research Council's Environmental Epidemiology Unit at Southampton General Hospital, that an observed excess of leukaemias appeared to be correlated with the radiation dosages received by fathers from Seascale working at Sellafield.

But the report also confirms that the excess of cancers could have been caused by a process of "population mixing", proposed by Leo Kinlen of the Radcliffe Infirmary in Oxford, in which the risk of childhood cancers is claimed to increase when people come to live in a geographically isolated area from other parts of the country.

Both the nuclear industry and its critics have drawn support for their arguments from the HSE report. The first claims that it confirms the lack of proof that the nuclear plant was to blame for the cancers; the second that it does nothing to undermine this hypothesis and strengthens the case that the plant could be to blame.

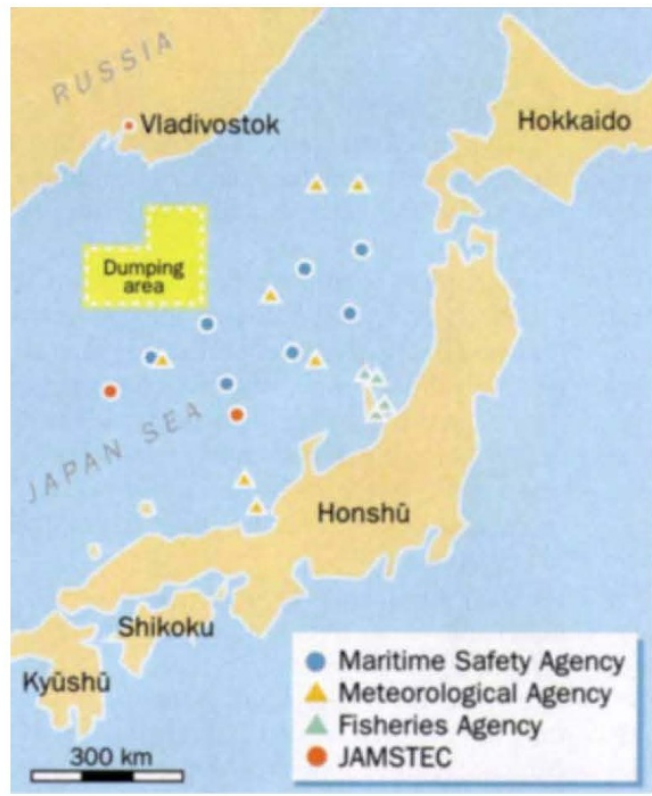

Japanese agencies visited numerous offshore survey sites earlier this year.

compared to the activities of the former Soviet Union. In March, Russia revealed that, since 1959 , more than 80,000 tons of low-level liquid waste, more than 5,000 containers of solid low-level waste, 34 ships packed full of waste, and 2 nuclear reactors (with fuel removed) had all been dumped in the Japan Sea in an area a few hundred kilometres south of the Russian port of Vladivostok.

Between April and June, the Japanese Meteorological Agency, the Fisheries Agency, the Maritime Safety Agency, and the Japan Marine Science and Technology Centre (JAMSTEC) all sent ships to analyse sea water, deep-sea sediments and fish for various radionuclides in a number of locations (see map).

No unusual levels of radioactivity were found, and at the end of August, Japan's Science and Technology Agency (STA) announced that "the results of the survey so far show that this ocean dumping is not something that has an effect on the health of our people".

But the conclusions are of limited value, as none of the surveys was able to collect samples in the actual dumping area, which lies within Russia's 200-mile exclusive economic zone. Investigations have been confined to areas off Japan's coast, tens to hundreds of kilometres distant from the dump site.

Japanese marine scientists need samples from the dumping region to reach definitive conclusions, and $\mathrm{Ja}$ pan has been pressing Russia to allow this. The joint meeting agreed to by Yeltsin, which will be held this week, is seen as a step in this direction.

An STA official says Japan hopes to conduct a full survey of the dumping region "this year or next". And, in addition to budgets already allocated this fiscal year, the agency has requested $¥ 306$ million (about \$3 million) for further surveys next fiscal year, which begins on 1 April 1994.

Russia itself is hoping to persuade Japan to provide financial support for the construction of a land-based facility for waste disposal. Japan is considering allocating part of an agreed $\$ 100$ million in grants for dismantling nuclear weapons for this purpose. But, even if the land-based facility is built and sea dumping stops, surveys will have to be continued for many years to monitor the effects of waste disposal over the past four decades. David Swinbanks

\section{Dumping boosts case for total ban}

Tokyo. Revelations that Russia has been continuing to dump nuclear waste in the Japan Sea (see above) may force Japan to support a total ban on the ocean dumping of nuclear waste at a meeting in London early next month.

The London Convention on ocean dumping was established in $\mathbf{1 9 7 5}$ to prevent contamination of the sea by nuclear waste. Japan became a party to the convention in 1980. The convention bans all dumping of high-level waste. And in 1983 and 1985, many of the countries belonging to the convention also agreed to a voluntary ban on dumping low-level waste.

Both Japan and Russia abstained from voting in 1985, and have therefore not committed themselves to the voluntary ban. But René Coenen, senior technical officer for the London Convention at the International Maritime Organization in London, says that, whatever the legal position, the recent dumping by Russia goes "against the spirit of the convention".

At a meeting in London on 8 November, seven proposals, ranging from a complete ban on dumping of radioactive waste to resumption of some dumping, will be discussed.

Until now, Japan has been undecided on how to vote because its nuclear power industry has been urging the government to retain an option on dumping. But following Japan's protests about Russia's activities in the Japan Sea, it will be hard for Japan not to vote for a permanent ban.

D.S. 